\title{
ENHANCEMENT OF THE POTENCY OF TYPHOID VACCINES WITH CALCIUM ALGINATE
}

\author{
M. Sterne and Gladys Trim \\ Wellcome Research Laboratories, Beckenham, Kent, England
}

\begin{abstract}
RENEWED interest in the possibility of using adjuvants to improve typhoid vaccines has been stimulated by the observation that topically formed calcium alginate greatly enhanced the response of mice to typhoid vaccine, although it was much less effective in enhancing the response to a number of viral vaccines and ineffective with diphtheria toxoid (Shapiro, Modai and Kohn, 1967; Kohn, Helering and Ben-Efraim, 1969). Because this work suggested that alginate might be a particularly suitable adjuvant for typhoid vaccines in man, we carried out a number of experiments to measure the degree of adjuvance that could be expected and to examine the influence of alginate on nonspecific factors known to be involved in the protection of mice against challenge with virulent Salmonella typhi (Edsall et al., 1959; Joó, Pusztai and Juhász, 1968; Sterne and Trim, 1970).
\end{abstract}

\section{MATERIALS AND METHODS}

Vaccine. Batch V980 typhoid vaccine was used throughout. This had been prepared by the heat-phenol method and standardised against both the WHO and the United States reference preparations. It had a potency of at least 8 United States units.

Alginate. This was obtained from Medical Alginates Ltd, as a mixture of 4 per cent. sodium alginate with 0.8 per cent. calcium gluconate. The alginate was mixed with the appropriate dilution of vaccine in the ratio of $1: 1$ for intraperitoneal and $2: 3$ for subcutaneous inoculation, the volumes administered being 0.2 and $0.5 \mathrm{ml}$ respectively. Thus, an intraperitoneal dose contained $4 \mathrm{mg}$ and a subcutaneous dose $8 \mathrm{mg}$ of sodium alginate.

Challenge. A suspension of fully virulent Salmonella typhi Ty2 was made in a mixture of casamino acids and dimethylsulphoxide (DMSO), distributed in ampoules and stored in a liquid nitrogen refrigerator. When required, an ampoule was thawed and the contents diluted to approximately 1000 organisms per challenge dose in a mixture of casamino acids and 5 per cent. hog gastric mucin. The challenge was inoculated intraperitoneally. The LD50 was determined for each experiment on a minimum of 40 mice.

\section{RESULTS}

Table I summarises the results of an experiment in which the vaccinating dose was given intraperitoneally in a total dose of $0.2 \mathrm{ml}$ according to the procedure described by Shapiro et al.

The marked adjuvance by alginate confirmed fully the observations of Shapiro et al. Since adjuvants that form local depots tend to prolong the immune response, a further experiment was done (table II) to examine the effect of increasing the interval between vaccination and challenge.

\footnotetext{
Received 12 Feb. 1970; accepted 30 Mar. 1970.

J. MED. MICROBIOL.-VOL. 3 (1970) 
TABLE I

The effect of alginate on the protection of mice by typhoid vaccine V980 given intraperitoneally

\begin{tabular}{|c|c|c|c|c|c|c|}
\hline \multirow{2}{*}{$\begin{array}{l}\text { Intraperitoneal } \\
\text { vaccine: } \\
\text { number of } \\
\text { organisms } \\
\text { in } 0.2 \mathrm{ml}\left(10^{6}\right)\end{array}$} & \multirow[b]{2}{*}{ Adjuvant } & \multicolumn{2}{|c|}{$\begin{array}{l}\text { Challenge dose* of } S \text {. typhi } \\
\text { Ty2 in } 5 \text { per cent. mucin }\end{array}$} & \multirow{2}{*}{$\begin{array}{l}\text { Number of mice } \\
\text { dead/number } \\
\text { challenged }\end{array}$} & \multicolumn{2}{|c|}{ Vaccine } \\
\hline & & $\begin{array}{l}\text { Number of } \\
\text { organisms }\end{array}$ & $\begin{array}{l}\text { Number of } \\
\text { LD50 }\end{array}$ & & $\begin{array}{l}\text { Estimated } \\
\text { ED50† } \\
\text { (with fidu- } \\
\text { cial limits) }\end{array}$ & $\begin{array}{l}\text { Relative } \\
\text { potency }\end{array}$ \\
\hline $\begin{array}{r}125 \\
25 \\
5 \\
1\end{array}$ & None & 723 & 402 & $\begin{array}{r}1 / 32 \\
3 / 32 \\
16 / 32 \\
18 / 32\end{array}$ & $\begin{array}{l}2 \cdot 20(0 \cdot 9 \\
4 \cdot 0) \times 10^{6}\end{array}$ & 1 \\
\hline $\begin{array}{r}125 \\
25 \\
5 \\
1\end{array}$ & Alginate & 723 & 402 & $\begin{array}{l}0 / 32 \\
0 / 32 \\
1 / 32 \\
3 / 32\end{array}$ & $0.05 \times 10^{6}$ & 50 \\
\hline
\end{tabular}

* Interval between vaccination and challenge 12 days.

$\dagger \mathrm{ED} 50=$ Dose of vaccine required to protect 50 per cent. of mice.

TABLE II

The effect of different intervals between vaccination and challenge on the protection of mice by typhoid vaccine $V 980$ containing alginate

\begin{tabular}{|c|c|c|c|c|c|c|c|}
\hline \multirow{2}{*}{$\begin{array}{c}\text { Intraperitoneal } \\
\text { vaccine: } \\
\text { number of } \\
\text { organisms } \\
\text { in } 0.2 \mathrm{ml}\left(10^{6}\right)\end{array}$} & \multirow[b]{2}{*}{ Adjuvant } & \multirow{2}{*}{$\begin{array}{l}\text { Days to } \\
\text { challenge }\end{array}$} & \multicolumn{2}{|c|}{$\begin{array}{l}\text { Challenge dose of } S \text {. typhi } \\
\text { Ty2 in } 5 \text { per cent. mucin }\end{array}$} & \multirow{2}{*}{$\begin{array}{l}\text { Number of mice } \\
\text { dead/number } \\
\text { challenged }\end{array}$} & \multicolumn{2}{|l|}{ Vaccine } \\
\hline & & & $\begin{array}{l}\text { Number of } \\
\text { organisms }\end{array}$ & $\begin{array}{l}\text { Number of } \\
\text { LD50 }\end{array}$ & & \begin{tabular}{c|} 
Estimated \\
ED50 \\
(with fidu- \\
cial limits)
\end{tabular} & $\begin{array}{l}\text { Relative } \\
\text { potency }\end{array}$ \\
\hline $\begin{array}{r}250 \\
50 \\
10 \\
2\end{array}$ & None & 13 & 925 & 37 & $\begin{array}{l}0 / 16 \\
0 / 16 \\
0 / 16 \\
4 / 16\end{array}$ & $0.5 \times 10^{6}$ & 15 \\
\hline $\begin{array}{r}250 \\
50 \\
10 \\
2\end{array}$ & None & 26 & 925 & 37 & $\begin{array}{r}0 / 16 \\
3 / 16 \\
9 / 16 \\
10 / 16\end{array}$ & $\begin{array}{l}6.7(2- \\
14) \times 10^{6}\end{array}$ & 1 \\
\hline $\begin{array}{r}10 \\
2\end{array}$ & Alginate & 13 & 925 & 37 & $\begin{array}{l}0 / 16 \\
0 / 16\end{array}$ & $0 \cdot 004^{*} \times 10^{6}$ & 1875 \\
\hline $\begin{array}{r}50 \\
10 \\
2\end{array}$ & Alginate & 26 & 925 & 37 & $\begin{array}{l}0 / 16 \\
2 / 16 \\
9 / 16\end{array}$ & $\begin{array}{r}2 \cdot 5(0.8- \\
4) \times 10^{6}\end{array}$ & 2 \\
\hline
\end{tabular}

* Estimated by extrapolation from the slope of other preparations. 
As in the previous experiment, alginate clearly enhanced the ability of typhoid vaccine to protect mice against a severe challenge. A noteworthy feature was the rapid fall in the protection elicited by both vaccines after the 12 th day post-vaccination. By the 26 th day the difference between the abilities of the two vaccines to protect had diminished sharply: the enhancement by the alginate had virtually ceased.

TABLE III

The effect of alginate on the protection of mice by typhoid vaccine V980 given subcutaneously

\begin{tabular}{|c|c|c|c|c|c|c|c|}
\hline \multirow{2}{*}{$\begin{array}{l}\text { Expt } \\
\text { no. }\end{array}$} & \multirow{2}{*}{$\begin{array}{l}\text { Subcutaneous } \\
\text { vaccine: } \\
\text { number of } \\
\text { organisms } \\
\text { in } 0.5 \mathrm{ml}\left(10^{6}\right)\end{array}$} & \multirow{2}{*}{ Adjuvant } & \multicolumn{2}{|c|}{$\begin{array}{l}\text { Challenge dose* of } S . \text { typhi } \\
\text { Ty2 in } 5 \text { per cent. mucin }\end{array}$} & \multirow{2}{*}{$\begin{array}{l}\text { Number of mice } \\
\text { dead/number } \\
\text { challenged }\end{array}$} & \multicolumn{2}{|c|}{ Vaccine } \\
\hline & & & $\begin{array}{l}\text { Number of } \\
\text { organisms }\end{array}$ & $\begin{array}{c}\text { Number of } \\
\text { LD50 }\end{array}$ & & $\begin{array}{l}\text { ED50 } \\
\text { (with fidu- } \\
\text { cial limits) }\end{array}$ & $\begin{array}{l}\text { Relative } \\
\text { potency }\end{array}$ \\
\hline \multirow[t]{2}{*}{1} & $\begin{array}{r}250 \\
50 \\
10 \\
2\end{array}$ & None & 1150 & 294 & $\begin{array}{r}0 / 16 \\
1 / 16 \\
12 / 16 \\
14 / 16\end{array}$ & $\begin{array}{c}13(7-22) \\
\times 10^{6}\end{array}$ & 2 \\
\hline & $\begin{array}{r}250 \\
50 \\
10 \\
2\end{array}$ & Alginate & 1150 & 294 & $\begin{array}{r}1 / 16 \\
4 / 16 \\
13 / 16 \\
16 / 16\end{array}$ & $\begin{array}{c}28(16-49) \\
\times 10^{6}\end{array}$ & 1 \\
\hline \multirow[t]{2}{*}{2} & $\begin{array}{r}250 \\
50 \\
10 \\
2\end{array}$ & None & 1525 & 254 & $\begin{array}{r}0 / 16 \\
1 / 16 \\
11 / 16 \\
14 / 16\end{array}$ & $\begin{array}{c}12(7-19) \\
\times 10^{6}\end{array}$ & 1 \\
\hline & $\begin{array}{r}250 \\
50 \\
10 \\
2\end{array}$ & Alginate & 1525 & 254 & $\begin{array}{r}0 / 16 \\
0 / 16 \\
11 / 16 \\
15 / 16\end{array}$ & $\begin{array}{l}12(7-20) \\
\times 10^{6}\end{array}$ & 1 \\
\hline
\end{tabular}

* Interval between vaccination and challenge 12 days.

This result was unusual. As a rule, the potency of " adjuved " relative to "unadjuved" vaccines increases with time. The decrease suggested that alginate was preferentially stimulating non-specific responses. Accordingly, we carried out experiments (table III) in which mice were vaccinated subcutaneously instead of intraperitoneally in order to avoid direct stimulation of peritoneal antibacterial mechanisms.

The two experiments agreed completely. Potency was not enhanced when the typhoid vaccine with alginate was injected subcutaneously. These experiments, in conjunction with that summarised in table II, suggested strongly that the alginate acted by stimulating antibacterial mechanisms in the peritoneum and not by enhancing specific immunity. More direct evidence of this was sought by examining the extent to which alginate alone or alginate combined with a heterologous antigen could increase resistance to typhoid challenge. 
TABLE IV

The effect of pretreatment with alginate on the resistance of mice to challenge with $S$. typhi

\begin{tabular}{|c|c|c|c|c|c|}
\hline $\begin{array}{l}\text { Expt } \\
\text { no. }\end{array}$ & Pretreatment & $\begin{array}{l}\text { Challenge dose* } \\
\text { of } S . \text { typhi Ty2 in } \\
5 \text { per cent. mucin }\end{array}$ & $\begin{array}{l}\text { Number of } \\
\text { mice dead/ } \\
\text { number } \\
\text { challenged }\end{array}$ & $\underset{\text { Ty2 }}{\text { LD50 }} \underset{\text { of }}{S}$ typhi & $\begin{array}{l}\text { Relative potency } \\
\text { of alginate in } \\
\text { pretreatment } \\
\text { as compared with } \\
\text { no pretreatment }\end{array}$ \\
\hline \multirow[t]{2}{*}{1} & $\begin{array}{l}\text { Alginate, by } \\
\text { subcutaneous } \\
\text { route }\end{array}$ & $\begin{array}{r}295 \\
59 \\
12 \\
2-3\end{array}$ & $\begin{array}{l}9 / 10 \\
8 / 10 \\
9 / 10 \\
4 / 10\end{array}$ & $3-4$ & 1 \\
\hline & None & $\begin{array}{r}295 \\
59 \\
12 \\
2-3\end{array}$ & $\begin{array}{r}9 / 10 \\
8 / 10 \\
10 / 10 \\
4 / 10\end{array}$ & $3-4$ & $\ldots$ \\
\hline \multirow[t]{2}{*}{2} & $\begin{array}{l}\text { Alginate, by } \\
\text { intraperitoneal } \\
\text { route }\end{array}$ & $\begin{array}{r}305 \\
61 \\
12 \\
2-3\end{array}$ & $\begin{array}{l}7 / 10 \\
4 / 10 \\
5 / 10 \\
2 / 10\end{array}$ & 44 & 8 \\
\hline & None & $\begin{array}{r}305 \\
61 \\
12 \\
2-3\end{array}$ & $\begin{array}{l}9 / 10 \\
8 / 10 \\
6 / 10 \\
3 / 10\end{array}$ & 6 & $\ldots$ \\
\hline
\end{tabular}

* Interval between pretreatment and challenge 12 days.

TABLE $\mathrm{V}$

The effect of alginate on non-specific resistance to S. typhi conferred by Bordetella pertussis vaccines

\begin{tabular}{|c|c|c|c|c|c|c|c|c|}
\hline \multirow{2}{*}{$\begin{array}{l}\text { Expt } \\
\text { no. }\end{array}$} & \multirow{2}{*}{$\begin{array}{l}\text { Vaccinating } \\
\text { dose of } \\
\text { Bord. pertussis } \\
\quad\left(10^{9}\right)\end{array}$} & \multirow{2}{*}{ Adjuvant } & \multirow{2}{*}{$\begin{array}{l}\text { Route } \\
\text { of } \\
\text { injection }\end{array}$} & \multicolumn{2}{|c|}{$\begin{array}{l}\text { Challenge dose* of } \\
\text { S. typhi Ty } 2 \text { in } \\
5 \text { per cent. mucin }\end{array}$} & \multirow{2}{*}{$\begin{array}{l}\text { Number } \\
\text { of mice } \\
\text { dead/ } \\
\text { number } \\
\text { challenged }\end{array}$} & \multicolumn{2}{|c|}{ Vaccine } \\
\hline & & & & $\begin{array}{c}\text { Number } \\
\text { of } \\
\text { organisms }\end{array}$ & $\begin{array}{c}\text { Number } \\
\text { of } \\
\text { LD50 }\end{array}$ & & $\begin{array}{c}\text { Estimated } \\
\text { ED50 }\end{array}$ & $\begin{array}{l}\text { Relative } \\
\text { potency }\end{array}$ \\
\hline \multirow[t]{2}{*}{1} & $\begin{array}{r}10 \\
3\end{array}$ & Alginate & Subcutaneous & 1285 & 105 & $\begin{array}{l}12 / 16 \\
16 / 16\end{array}$ & $\cdots$ & 1 \\
\hline & $\begin{array}{r}10 \\
3\end{array}$ & None & Subcutaneous & 1285 & 105 & $\begin{array}{l}13 / 16 \\
15 / 16\end{array}$ & $\cdots$ & 1 \\
\hline \multirow[t]{2}{*}{2} & $\begin{array}{r}10 \\
3\end{array}$ & Alginate & Intraperitoneal & 1525 & 254 & $\begin{array}{l}5 / 16 \\
6 / 16\end{array}$ & $0 \cdot 15$ & 9 \\
\hline & $\begin{array}{r}10 \\
3\end{array}$ & None & Intraperitoneal & 1525 & 254 & $\begin{array}{r}8 / 16 \\
11 / 16\end{array}$ & $1 \cdot 29$ & 1 \\
\hline
\end{tabular}

* Interval between vaccination and challenge 12 days. 
Mice were pretreated with alginate alone, either subcutaneously or intraperitoneally, and challenged with S. typhi 12 days later (table IV). We also examined the influence of alginate on the protection against typhoid provoked by a heterologous antigen, pertussis vaccine (table V), which has been shown to protect whether given subcutaneously or intraperitoneally (Sterne and Trim).

Thus, pretreatment of the peritoneum with alginate alone (expt 2, table IV) increased the resistance of mice to a $S$. typhi challenge 12 days later. No discernible effect followed subcutaneous inoculation. Similarly (table V) alginate enhanced the resistance to typhoid challenge induced by pertussis vaccine given intraperitoneally, but had no effect when this was given subcutaneously; despite the fact that pertussis vaccine alone, given subcutaneously, can induce non-specific resistance to a typhoid challenge.

\section{Discussion}

Shapiro et al. (1967) and Kohn et al. (1969) showed that alginate enhanced the immunity induced in mice by typhoid vaccines. Our results confirmed this, but only for vaccine given intraperitoneally; no enhancement whatever occurred when vaccine was given subcutaneously. Moreover, the enhancement by the alginate, which was very evident at the 12th day after vaccination, fell steeply thereafter and had virtually ceased by the 26th day.

Had alginate behaved as a depot adjuvant, enhancement should have been evident after subcutaneous as well as after intraperitoneal vaccination and should have increased with time rather than fallen steeply. It seemed probable, therefore, that the alginate had stimulated non-specific mechanisms; a possibility strengthened by the finding (table V) that alginate also enhanced the non-specific resistance to typhoid challenge by pertussis vaccine. Although this non-specific resistance occurs after both subcutaneous and intraperitoneal inoculation of the heterologous antigen (Sterne and Trim, 1970), the enhancement by alginate was, as in the case of typhoid vaccine, confined to inoculations made intraperitoneally. Finally, it could be shown (table IV) that alginate alone, when given intraperitoneally, induced resistance to a typhoid challenge 12 days later.

Since alginate enhanced the resistance induced by specific or non-specific antigens, provided these were injected intraperitoneally, and since alginate alone, given intraperitoneally, induced resistance, it is probable that the enhancement of the response to typhoid vaccine resulted from the independent stimulation of antibacterial mechanisms of the peritoneal cavity by the alginate. The ephemeral character of the adjuvance supports this view.

The striking difference between the results of intraperitoneal and subcutaneous vaccination with the adjuved vaccines emphasises the need for caution in extrapolating results obtained with intraperitoneal inoculation of mice to subcutaneous vaccination of man. Moreover, the ephemeral character of both adjuvance and protection in mice compared with the long-persisting immunity that follows a single inoculation of typhoid vaccine in man (Ashcroft et al., 1967) increased the probability that the protection measured by the assay 
method in which mice are vaccinated by intraperitoneal injection of antigen is not that concerned with immunity to typhoid in man.

\section{SUMMARY}

The potency of typhoid vaccine for mice could be increased 50 -fold by incorporation in alginate. This adjuvance was evident only after intraperitoneal inoculation. It waned rapidly and had virtually ceased 26 days after vaccination.

Similarly, alginate increased the resistance to typhoid challenge of mice given a heterologous antigen, pertussis vaccine, provided this was injected intraperitoneally.

Alginate alone, when injected intraperitoneally, but not when injected subcutaneously, increased the resistance of mice to typhoid challenge.

It was concluded that the adjuvance of typhoid vaccine by alginate resulted from stimulation of antibacterial mechanisms in the peritoneal cavity and was independent of any specific immune mechanism.

\section{REFERENCES}

Ashcroft, M. T., Singh, B., Nicholson, 1967. Lancet, 2, 1056.

C. C., RrTche, J. M., Sobryan, E., AND WILliams, F.

Edsall, G., Carlson, Margaret C., 1959. Bull. Wld Hith Org., 20, 1017.

Formal, S. B., AND BENENSON, A. S.

Joó, I., Pusztai, Zsuzsanna, AND JuhásZ, 1968. Z. ImmunForsch. exp. Ther., 135, 365. VERA P.

Kohn, A., Helering, I., ANd Ben-Efraim, 1969. Int. Archs Allergy Appl. Immun., 36, 156. S.

Shapiro, A., ModaI, Y., And Kohn, A. 1967. J. Appl. Bact., 30, 304.

Sterne, M., ANd Trim, Gladys . . . 1970. Symp. Ser. Perm. Sect. Microbiol. Standard., vol. 15 , in press. 